\title{
Future Package (FP) Financing Using Murabahah Contract for Pre-Prosperous Families in Bank Tabungan Pensiunan Nasional Syariah (BTPNS) of Solok City
}

\author{
Risca Mia Audia; Yaswirman; Rembrandt \\ Faculty of Law, Andalas University, Padang, Indonesia \\ http://dx.doi.org/10.18415/ijmmu.v6i5.1077
}

\begin{abstract}
Future Package (FP) financing is one of the products of Bank Tabungan Pensiunan Nasional Syariah (BTPNS). This FP program is aimed specifically at women who want to develop or who want to start a business. Based on observations in the field, after the financing has been provided to customers, there are several customers who have arrears in installments. Thus, it raises discrepancies such as what is regulated in the fatwa of the National Sharia Council (DSN) No. 04/DSN-MUI/IV/2000 concerning Murabahah Contract Financing that the customer must pay the price of the goods agreed upon at a certain agreed period of time. The formulation of the research problems includes: (1) what are the criteria for FP financing for pre-prosperous families? (2) how is FP financing viewed from Islamic law? (3) what are the problems with the FP program? and (4) how does the bank cope with it? This research applies an empirical juridical problem approach in which the source of data is obtained by looking at the legal provisions that are connected with facts in the field. The data types consist of primary data from the field and secondary data from books and literature. Problems with non-current installment payments by some customers started with declining business incomes. Thus, banks must make regular collection efforts and the active role of groups. The suggestion from this research is that customers need to increase their sense of responsibility to pay installments on time.
\end{abstract}

Keywords: Future Package (FP) Financing; Bad Debt Payment; Bank Tabungan Pensiunan Nasional Syariah (Btpns)

\section{Introduction}

Sharia banks in Indonesia were established in line with the rolling of banking reforms marked by the enactment of Law No. 7 of 1992. At that time, sharia banks were not yet referred to as sharia banks but profit-sharing banks. However, it is a milestone that needs to be noted in the phase of establishing sharia banks in Indonesia (Hosen \& Muhari, 2013). Sharia banking in Indonesia has experienced rapid development so that people are starting to get to know what is called sharia banks. ${ }^{1}$ After initially doubting its operational system, sharia banks have now shown very good progress (Sadalia \& Kautsar,

\footnotetext{
${ }^{1}$ BTPN Syariah, History of Sharia Banking in Indonesia, Module 2, page 2.
} 
2018). Although its development is a bit late compared to other Muslim countries, sharia banking in Indonesia will continue to grow. ${ }^{2}$

Sharia banks provide financial services that are commonly used in business transactions or household financial transactions that have similarities to conventional bank financial services products such as clearing, transfers, bank guarantees, and money exchanges (How et al., 2005). In addition, sharia banks also have financial service products that are not owned by conventional banks; for instance, a pawn. The main difference in existing financial services in conventional banks lies in the contract agreement. ${ }^{3}$

FP is an integrated and productive financing program based on a contract of wakalah wal murabahah which is intended for a group of women in rural areas who already have a business or to build a type of business but do not have additional capital and access to the banking world (Adnan \& Muhamad, 2007). This FP financing program emerged to assist pre-prosperous families in building and managing businesses. Thus, FP financing is only focused on financing productive businesses.

In this case, the funds channeled to each customer can be used to manage the type of business. Thus, these funds can grow and generate profits for customers themselves in completing the proposed financing as well as for the bank in recovering the funds channeled and the profit sharing from these financing. In addition, BTPNS routinely continues to provide assistance and supervision of the use of funds provided to customers for the achievement of a sustainable and measurable FP empowerment program so that the provision of financing is right on target. ${ }^{4}$

Future Package (FP) is a group concept financing. It consists of financing facilities, savings, and insurance benefits with sharia principles provided to customers through the Center for Regular Meetings (PRS). In this case, FP financing is murabahah financing aimed at meeting customer needs in the form of working capital needs (Ismal, 2009). Purchases of customer needs, as explained above, are represented to customers through a wakalah contract and must be included with the data of the items to be purchased. All customers are required to submit proof of purchase of legitimate goods as proof of the use of financing (Wahab, 2006).

After financing in the form of a Future Package is provided by Bank Tabungan Pensiunan Nasional Syariah (BTPNS) to its customers, there are several problems that bank experiences in the field. After the bank provides the financing, customers have difficulty returning the financing on time so that it causes arrears in installment payments. In addition, the financing provided by the bank should be used for business development, but customers use it for other purposes.

In this case, the customer has the responsibility to pay for the installment specified by the bank as agreed during the contract. This will also spell out the responsibilities of the husband in Islamic law with the existence of a financing program specifically for women.

\footnotetext{
${ }^{2}$ Ibid, page 2 .

${ }^{3}$ Ibid, page 67.

${ }^{4}$ http://www.btpnsyariah.com/produk), accessed on July 10 2019, at 3:00 p.m. Western Indonesia Time.
} 


\section{Research Method}

This research applies an empirical juridical problem approach which is an approach through legal research by looking at the applicable legal provisions and then linking them to the facts in the field related to the problems that this research discusses.

The nature of the research is descriptive that is describing the object or problem that is happening in the research. In other words, it is a study whose main objective is to describe social reality that is so complex that social relevance can be achieved. It is about the process of lending funds to customers for business development based on sharia banking principles. The researcher obtained primary data by conducting interviews with staff at BTPNS who knew how to finance the Future Package which is implemented using murabahah contract for pre-prosperous families at Bank Tabungan Pensiunan Nasional Syariah (BTPN) of Solok City. Secondary data include: primary, secondary, and tertiary legal materials.

Data collection technique in research was carried out through direct interviews in the collection of social facts as material for the study of empirical law. It was performed through direct question and answer where all questions are arranged systematically, clearly and directed in accordance with the legal issues raised in the research. This direct interview is intended to obtain true and accurate information from a predetermined source. Through this interview, all information about what they want is noted or recorded properly. ${ }^{5}$ After the data were obtained or collected, the authors analyze the data qualitatively by collecting data, qualifying, then connecting theories related to the problem, and finally drawing conclusions to determine the results.

\section{Future Package Financing by Bank Tabungan Pensiunan Nasional Syariah (BTPNS) in Terms of Islamic Law}

\section{FP Financing Connected with the Rights and Obligations of Husband and Wife}

BTPNS product in terms of financing is Future Package (FP) product. Future Package is an integrated program of BTPNS that is given to a group of women in rural areas who want to try and have a dream to change their lives but do not have access to banking services. BTPNS routinely conducts empowerment programs that are sustainable and measurable. Women's empowerment is a systematic and planned effort to involve women in various development programs by providing equal opportunities and roles with men to increase productivity, dignity, and integrity.

This FP program targets specifically women who want to open or develop a business. So, in this case, those who work are women. Legal issues are about the position of a husband in Islamic law that the husband or the person who works is husband.

As a legal relationship, marriage creates rights and obligations for husband and wife. "Right" is something that belongs to or can be owned by a husband or wife that arises because of their marriage. In addition, "obligation" is something that must be done or carried out by a husband or wife to fulfill the rights and from other parties. Rights and obligations in family law can be divided into three types: (a) rights and obligations of husband and wife; (b) rights and obligations between parents and children; (c)

\footnotetext{
${ }^{5}$ Bahder Johan Nasution, Legal Research Method, page 167-168.
} 
rights and obligations between children and parents when their parents are getting old. The rights and obligations of a husband and wife are the rights and obligations arising from a marriage. ${ }^{6}$

Islam has realized that building a household is a two-party agreement between husband and wife. Therefore, everything must be discussed together. This includes procedures for the division of domestic work. The division of work must be discussed with the husband and wife can achieve peace in the household. An agreement must be made so that no one party is harmed. By realizing that marriage aims to achieve peace between the two parties that go through it, it will be difficult to achieve if the division of domestic work is unfair. ${ }^{7}$

Husband and wife actually have moral and material responsibilities. Each husband and wife must know their obligations in addition to their rights because there are many people who only know their rights but ignore their obligations. The existence of rights and obligations between husband and wife in domestic life can be seen in several verses of the Qur'an and some of the Prophet's Hadith.

These verses explain that the wife has rights and the wife also has obligations where the wife's obligations are rights for the husband. The wife's rights are the same as the husband's rights. As stated in the verse, the rights and position of the wife are equal or balanced with the rights and position of the husband. Even so, the husband has a higher level of position as head of the family as implied by the end of the verse. The rights of the wife that must be fulfilled by the husband are as follows:

1. Rights relating to materials such as dowry and maintenance.

2. Rights that are not related to the material such as being fair among wives if the husband marries more than one wife and does not take actions that have a negative impact on the wife.

\section{Position of Wife Who Works According to Islamic Law}

Income comes from the word anfaqa which means to spend. So, living means meeting all the needs and necessities of life including food, clothing, shelter, household costs, treatment for the wife in accordance with the circumstances, and also the cost of children's education. Based on the definition of the living and some of its characteristics, a living can be defined as a person's obligation that arises as a result of an act that contains the burden of responsibility in the form of payment of a number of costs to meet basic or secondary needs for something that is within the dependents.

Based on field interviews, the wife is allowed to work under some considerations:

1. She obtains permission or accepts from husband.

A woman cannot leave her home without permission from her husband. Therefore, a woman can work with her husband's permission and of course with clear work objectives and does not bring mudharat (loss).

2. It does not cause backbiting.

To avoid backbiting, women should avoid jobs where men and women mix. This is why the position of women in Islam is glorified. In addition, they must always guard themselves from backbiting and danger outside the home.

\footnotetext{
${ }^{6}$ http://ejournal.uinmalang.ac.id/index.php/syariah/article/download/3207/5040. Eko Setiawan, "The Dynamics of Islamic Family Law Renewal in Indonesia" the article was accessed on July 20, 2019 at 3:00 p.m. Western Indonesia Time.

${ }^{7}$ Istiadah, “Building a Solid Family Ark”, (Jakarta: PT Gramedia Pustaka Utama), page 36.
} 
3. She can take care of herself.

When out of the house, women should protect themselves by covering their genitals and not wearing jewelry to avoid the risk of crime.

4. She does not neglect her responsibilities as a wife.

Since the main responsibility in a family is borne by the husband, the wife works to help the husband's economy. So, this FP program is good for pre-prosperous family communities who want to open a business to help their husbands or meet their daily needs. If women are allowed to work, women only help and not carry out basic obligations or become leaders in the family.

Regarding FP program that specializes in women, there is no prohibition for a wife to work as long as she does not neglect her obligations as a wife. So, this FP program is good for helping the family economy. However, it is not a source of basic livelihood. Seeing the current economic conditions, if the husband's income is low and insufficient to meet daily needs, especially for clothing, food, shelter, it will cause other problems such as children who cannot continue schooling, malnutrition, uncomfortable living, and others. ${ }^{8}$

Therefore, the FP program plays a role where women are considered more disciplined, more respectful of loans, more efficient, and smarter in managing finances. In marriage, a woman is placed in an honorable position, she is needed as a human being who has perfect human rights. Aside from having dowry rights, women also have a living right which is basically the responsibility of the husband.

Related to the BTPNS program that specializes in women to open businesses or work, it does not mean removing the husband's responsibility to support his wife. The husband continues to carry out his responsibilities as head of the family. However, if problems in the family economy occur, especially when the husband does not have a steady income, the wife can help to meet family needs. It is the purpose of this FP program, which is to create a better life.

\section{Problems with Future Package Financing by Pre-Prosperous Family Customers and How BTPNS of Solok City Copes with It}

\section{Financing Problems and their Categories}

The implementation of the Future Package (FP) program from BTPNS encountered several problems in the case of non-smooth installment payments. Based on the provisions of the National Sharia Council Fatwa No: 04/DSN-MUI/IV/2000 related to the general provisions of murabahah in sharia banks, it is stated that the customer pays the agreed price for a certain agreed period of time.

FP financing provided by banks to customers which is then used to develop the business. However, in the middle of the road when going to pay the installment, irregularities occur in the form of arrears in payment or payment is not timely due to several factors as follows:

1. Decreased business revenue.

2. Business money is used for other purposes; for instance, children school fee.

3. Lack of attention from families, especially husbands who are supposed to be responsible for paying installments.

\footnotetext{
${ }^{8}$ Interview with Muhammad Khilal, Ministry of Religion for Religious Counseling, September 11, 2019.
} 
4. Financing money that is misused for the purchase of goods outside of business development. ${ }^{9}$

The use of community money (including solidarity money and cash) and/ or use of funds outside of business proceeds for payment of installments is an indication of the customer's problem in question. The bad financing referred to is financing that has a bad/ good status. However, the installment payment uses solidarity/ cash money due to decreased ability to pay to customers or difficulties in making installment payments from the results of their own business. Other forms of financing problems are used for consumptive personal interests such as paying installments, buying a mobile phone, renovating a house, etc. So, the money that should have been used for business runs out of buying unproductive goods.

In this provision, bad debt is financing which is still current (collectible) or non-current with installment payments that have used solidarity money, cash and/or savings (bad financing) due to decreased ability to pay customers and/or difficulty making installment payments from the results of his/her own efforts.

By considering the principle of prudence in financing according to applicable regulations, the status of bad financing can be categorized as follows:

\section{Collectability Based on the Number of Days in Arrears for Installments/Days Past Due (DPD)}

Bad conditions are presented in the following table:

\begin{tabular}{|c|c|c|}
\hline Collectability & DPD & $\begin{array}{c}\text { Number of Installment Periods with } \\
\text { No Payment }{ }^{*} \text { ) }\end{array}$ \\
\hline Smooth & 0 & - \\
\hline Special Mention & $1-90$ & 1 to 6 times the installment period \\
\hline Less Smooth & $91-120$ & 7 to 8 times the installment period \\
\hline Doubted & $121-180$ & 9 to 12 times the installment period \\
\hline Bad & $>180$ & 12 times the installment period \\
\hline
\end{tabular}

*) Financing with an installment period is every 2 weeks.

\section{Collectability Based on Special Conditions}

On special conditions:

1. The customer is not known to exist, including if the person concerned is working in another city or country (being a migrant worker) and/or

2. The customer has no more business prospects (the customer's business is stopped or the customer's ability to pay is lost, which makes it less likely that the bank will get a refund according to the applicable conditions).

\footnotetext{
${ }^{9}$ Interview with Arisse Putri, Community Officer (CO) of Bank Tabungan Pensiunan Nasional Syariah (BTPNS) in Solok City, June 22, 2019.
} 
Then, the quality/ collectability of the customer's financing can be categorized as bad (collectability 5). Determination of collectability 5 (bad) based on the specific conditions above must be supported by reports and documentary evidence in the form of a statement stating the condition of the customer from the local apparatus at least in the form of a certificate signed by the head of the center and all members of the center. ${ }^{10}$

\section{Force Majeure Condition}

The aim of this provision is the occurrence of natural disasters and disasters that result in damage or destruction of customer property, deteriorating health and/or physical ability of customers to conduct business that will directly result in reduced or loss of ability to pay customers for financing due to an accident or disaster in the form of an earthquake, volcanic eruptions, floods, landslides, fires, riots or chronic diseases to customers and their families, and death.

Based on the results of interviews in the field of 2 (two) customers whose installment payments were poor; the cases are as follows:

1. Customer A, the financing is used to sell cucumbers that get a loan of IDR 2,000,000 with 25 installments and the installment is IDR 104,000 per 2 weeks. Customer A encountered problems in the middle of the installment due to several factors:

a. Business income has decreased, planting cucumber fruit only lasts for 2 months after it stopped due to unfavorable weather conditions causing fruit that is not good for market. Therefore, the business was stopped.

b. The condition of a husband who is no longer working because he is no longer able to continue paying rent. Usually, husband works as barber so every day they got income. However, after the husband stops working, there is no more income to help his wife pay for the installment.

c. The results from wages are insufficient because they have to pay motorcycle installments, buy groceries for daily needs, meet the needs of children for school and family, so they have not been able to set aside money to pay for installments.

2. Customer B, the financing is used for the goat livestock business and selling snacks, customers get a loan of IDR 5,000,000 with 25 installments of IDR 260,000 per two weeks. Customer B experiences payment problems in the middle of the installment due to several factors:

a. Customer B's goat is ill so that goat sales are declining.

b. The husband works odd jobs so he does not get a steady income each month. The husband earns income if there is project work unless the husband cannot help paying for the installment.

c. The business of snacks. She only gets IDR 20,000 a day. So, the money is used to meet daily needs such as buying rice, shopping for children and others. ${ }^{11}$

Meanwhile, for customers whose installments are running smoothly, they do not experience a decline in business so that they can set aside a portion of money from their business every day to pay for the installment and to save. If the business has decreased, there is savings that they can use to pay for the installment.

\footnotetext{
${ }^{10}$ BTPNS, Module 5 page 23.

${ }^{11}$ Interview with Customers A and B who experienced bad payment installments at Bank Tabungan Pensiunan Nasional Syariah (BTPNS) in Solok City, July 2, 2019.
} 


\section{Efforts to Manage Bad Financing}

In dealing with problems in the financing, there are several efforts and treatments that can be carried out including:

\section{Bank}

The bank will make maximum efforts to restore the status of refinancing smoothly and/or to complete financing that is categorized as bad financing by doing:

\section{Collection}

Bad Financing Collection

Collection is carried out to customers who have used a minimum of 1 (one) solidarity money.

a. Collection must be carried out on an ongoing basis through internal groups and by visiting the customer's residence to obtain a refund and identify the main causes of bad financing so that the best alternative financing settlement for the customer can be determined.

b. Collection by the supervisor of the center (and the Deputy Manager of the Center/ Manager of the Center) must be done politely and professionally in accordance with the bank's code of ethics. The supervisor of the center continually comes to the customer's residence to get a refund and identifies the main causes of difficulties in paying for the installment so that alternative solutions can be determined properly. If the customer runs away or moves outside the area, then the installation is the responsibility of the husband or heirs whose names are listed on the form when signing the contract.

c. Each collection process and the results of the visit must be reported in the form of a visit report signed by the Central Officer (PS)/ Deputy Central Manager / Central Manager. ${ }^{12}$

d. If the cause of a customer not fulfilling his/her obligations can be identified from the results of the visit, the Sharia Mobile Marketing Team (MMS) proposes the following:

1) For customers who died, the team made an insurance claim.

2) For customers who meet the slow lane criteria, rescheduling financing or adjustments / relief in the process of settlement for customers can be performed.

\section{Active Role of Groups}

The active role of groups in the recovery of bad financing is in accordance with the concept of community financing and the application of a culture of courage to try, discipline, work hard, and help each other. In this product package, each group member in principle must have care and commitment among members to help if other group members experience difficulties. ${ }^{13}$

Therefore, the Sharia Mobile Marketing Team (MMS) must encourage and ensure the active role of the head of the center, the head of the group, and each group member in the process of recovering bad financing, among others by:

a. Collection and use of solidarity money for installment payments for customers who have difficulty paying in installments to the group concerned.

\footnotetext{
${ }^{12}$ Interview with Arisse Putri, Community Officer (CO) of Bank Tabungan Pensiunan Nasional Syariah (BTPNS) in Solok City, June 22, 2019.

${ }^{13}$ BTPNS, Module 5 page 24.
} 
b. Members also assisted the collection process carried out by the Sharia Mobile Marketing team (MMS) and encouraged and invited members who had difficulty staying active in attending the Central Routine Meeting (PRS).

c. Provide recommendations for group members who are experiencing difficulties (decreased ability to pay) but still have good faith to comply with the provisions and continue their efforts to follow the slow track program.

\section{Commitment with Customers}

It is carried out by:

a. Rescheduling with the customer and determining when the installment payment will be made, how much installment will be paid which is included in the collection visit paper.

b. Deduction of customer savings for installment payments. Voluntary savings can be used to pay. However, if the savings are not sufficient, then the customer's mandatory savings will be used for installment payments (mandatory savings of $10 \%$ of the loan, can be taken after the customer has paid the payment or continue the cycle).

c. Billing by the Central Board of Trustees (and the Center Deputy Manager) must be carried out politely and professionally in accordance with the bank's code of ethics.

\section{Adjustment of Fulfillment Financing Obligations through Restructuring (Slow Track)}

Restructuring financing ("slow track") is an effort to recover financing by banks so that customers can settle their obligations to the bank in accordance with their payment capabilities. It is provided for customers who are experiencing difficulties but still have the willingness to pay and the ability to do business (have the good faith to comply/ follow the financing program from the bank and continue their business so that they are still possible to complete financing from the income of the business they run. Restructuring is carried out among others by:

a. Rescheduling

The extension of the financing period is due without changing the remaining customer obligations that must be paid to the bank.

b. Reconditioning

Re-establishing financing conditions, including changes in payment schedules, number of installments, time periods, and/or discounts as long as it does not add to the remaining customer obligations that must be paid to the bank.

c. Customer condition

d. The slow track can be proposed for customers who are experiencing difficulties and still have a business (have a willingness to pay and the ability to do business) with the following conditions:

1) Use of community money (solidarity money and/or cash) for 2 (two) consecutive installments and

2) Cutting customer savings to pay for installments

3) Willingness to follow the prerequisites of financing and ability to pay (willingness to pay and ability to do business) is evidenced by:

e. Discipline for the presence of the Central Routine Meeting.

f. Group and/or center recommendations. 
g. According to the results of business verification after obtaining financing (among others through business monitoring/ surprised visit), customers still have a business. ${ }^{14}$

Related to handling this financing problem, as a funding provider, the bank carries out its duties in accordance with the stipulated provisions. In this case, the theory of legal certainty is used to solve the problem because it includes the rules set by the bank in solving problems in the field including noncurrent payments. The bank charges customers whose payment is bad. If the customer is not at home at the meeting, the bank will ask the customer's family. After that the bank can use $10 \%$ of savings owned by customers. It also requires the active role of the group leader to remind members of their responsibilities or obligations to pay installments.

\section{Conclusion}

Based on the results of the research above, the author can conclude the following points:

1. The criteria for financing a Future Package (FP) with a murabahah contract for pre-prosperous families at BTPNS in providing financing is for adult women who want to establish or develop a business. In this case, BTPNS sets the age of 18 for those who are married and 21 years for those who are not married. BTPNS specializes women because they are considered more disciplined in terms of financial management.

2. In terms of Islamic law, the BTPNS Future Package financing program is good in terms of helping the family economy. According to the Ministry of Religion, this program is specifically for women to help their husbands not become the head of the family because the position of the wife is a servant rather than the main. Seeing the current economic conditions, if only the husband is working, it will be very difficult to be able to meet the economic needs of the family, the wife is allowed to work as long as she gets her husband permission and bless and does not cause defamation in the community.

3. Regarding financing issues of the Future Package (FP) by pre-prosperous family customers and how BTPNS has overcome them, the bank will make maximum efforts to restore the status of refinancing smoothly and/ or to complete financing categorized as bad financing by conducting:
a. Collection
b. Adjustments to fulfill financing obligations through restructuring (slow track)
c. Bookkeeping and Collection Deletion

The settlement of bad financing is related to the theory of legal certainty and the theory of responsibility that in solving problems in the field with customers who are in arrears, the bank must do so in accordance with the stipulated conditions and be responsible for resolving these problems. It is an obligation as a banker and the customer is also responsible for paying it until the allotted time.

\footnotetext{
${ }^{14}$ BTPNS, Module 5 page 31.
} 


\section{References}

\section{Journal}

Hosen, M. N., \& Muhari, S. (2013). Efficiency of the sharia rural bank in Indonesia lead to modified camel. International Journal of Academic Research in Economics and Management Sciences, 2(5), 34.

Sadalia, I., \& Kautsar, M. H. (2018). Analysis of the efficiency performance of Sharia and conventional banks using stochastic frontier analysis. Banks and Bank Systems, 13(2), 27.

Adnan, M. A., \& Muhamad, M. (2007). Agency problems in mudarabah financing: the case of sharia (rural) banks, Indonesia. International Journal of Economics, Management and Accounting, 15(2).

Ismal, R. (2009). Assessing moral hazard problem in Murabahah financing. Journal of Islamic Economics, Banking and Finance, 5(2), 101-112.

Wahab, A. R. A. (2006, February). Takaful Business Models-Wakalah based on WAQF. In Second International Symposium on Takaful (pp. 1-23).

How, J. C., Karim, M. A., \& Verhoeven, P. (2005). Islamic financing and bank risks: the case of Malaysia. Thunderbird International Business Review, 47(1), 75-94.

\section{Legislation}

The Quran.

Hadith.

Law No. 1 of 1974 concerning Marriage.

Law No. 10 of 1992 concerning Development of Population and Family Prosperous Development.

Law No. 23 of 1999 concerning Bank Indonesia.

National Sharia Council Fatwa No. 04/DSN-MUI/IV/2000 concerning Murabahah Financing.

Bank Indonesia Regulation No. 9/19/PBI/2007 dated 17 December 2007 concerning the Implementation of Sharia Principles in Funds Collection and Funds Distribution and Sharia Bank Services.

Law No. 21 of 2008 concerning Sharia Banking.

\section{Copyrights}

Copyright for this article is retained by the author(s), with first publication rights granted to the journal.

This is an open-access article distributed under the terms and conditions of the Creative Commons Attribution license (http://creativecommons.org/licenses/by/4.0/). 